\title{
Burrowing Crabs Weaken Mutualism Between Foundation Species
}

\author{
Marlous Derksen-Hooijberg, ${ }^{1 *}{ }_{\circledast}$ Tjisse van der Heide, ${ }^{1,2,3}$ \\ Leon P. M. Lamers, ${ }^{1}$ Annieke Borst, ${ }^{1}$ Alfons J. P. Smolders, ${ }^{4}$ \\ Laura L. Govers, ${ }^{1,3}$ Jasper R. H. Hoogveld, ${ }^{1}$ and Christine Angelini ${ }^{5}$
}

\begin{abstract}
${ }^{1}$ Department of Aquatic Ecology and Environmental Biology, Institute for Water and Wetland Research, Radboud University, Nijmegen, The Netherlands; ${ }^{2}$ Department of Coastal Systems, NIOZ Royal Netherlands Institute for Sea Research and Utrecht University, Den Burg, Texel, The Netherlands; ${ }^{3}$ Conservation Ecology Group, Groningen Institute for Evolutionary Life Sciences, University of Groningen, Groningen, The Netherlands; ${ }^{4} B$-WARE Research Centre, Nijmegen, The Netherlands; ${ }^{5}$ Environmental Engineering Sciences, Environmental School for Sustainable Infrastructure and the Environment, University of Florida, Gainesville, Florida, USA
\end{abstract}

\begin{abstract}
Foundation species often interact with each other and co-create habitat upon which other species depend. Whether the presence of these facilitated species feeds back to mediate the growth and resilience of the foundation species themselves, and influence the strength of their interactions, remains poorly understood. In a 16-month field experiment in a southeastern US salt marsh, we tested how the overlapping presence of two foundation species, cordgrass (Spartina alterniflora) and ribbed mussels (Geukensia demissa), influences the abundance of facilitated species, specifically burrowing crabs (mainly Uca pugnax), and how crabs, in turn, affect each foundation species and their mutualistic interaction. Mussel aggregations enhanced crab abundance 3.9-fold, which in turn reduced both mussel and cordgrass growth and stifled cordgrass
\end{abstract}

Received 15 January 2018; accepted 24 August 2018; published online 12 October 2018

Electronic supplementary material: The online version of this article (https://doi.org/10.1007/s10021-018-0301-x) contains supplementary material, which is available to authorized users.

Author contributions M.D.H., C.A., T.v.d.H., A.S. and L.P.M.L. designed the experiment. M.D.H., C.A., T.v.d.H., J.R.H.H., A.S., A.B. and L.P.M.L. conducted the field experiment. L.L.G. and M.D.H designed and conducted the field survey. M.D.H. and T.v.d.H. analyzed the data. M.D.H. wrote the first draft of the manuscript, and all authors contributed to revisions and gave approval for publication.

*Corresponding author; e-mail: m.hooijberg@science.ru.nl recovery after a simulated disturbance. Porewater and plant tissue analyses suggest crabs reduced cordgrass growth by reducing nitrogen availability, damaging roots, and potentially interfering with mussel deposition of nutrient-rich pseudofeces. A five-site field survey along $700 \mathrm{~km}$ southeastern US coastline revealed that cordgrass biomass and crab abundance are consistently higher in mussel aggregations. Furthermore, cordgrass biomass correlated negatively with crab abundance, supporting our experimental findings and the hypothesis that facilitated biota can negatively impact the foundation species upon which they depend. We anticipate that such negative, but non-lethal, feedbacks between foundation species and the biota they facilitate may be a common but overlooked phenomenon controlling foundation species growth and interactions in a wide range of ecosystems.

Key words: foundation species; Uca pugnax; salt marsh; mutualism; Spartina alterniflora; Geukensia demissa.

\section{ManusCRIPT Highlights}

- The cordgrass-mussel mutualism strongly enhances the abundances of associated species. 
- Facilitated species negatively feed back to weaken this mutualism and salt marsh resilience.

- Survey of US coastline demonstrates widespread occurrence of these interactions.

\section{Data Accessibility}

The data supporting the results of this manuscript will be archived in the public repository: Data Archiving and Networked Services (DANS) EASY at https://doi.org/10.17026/dans-zc8-hcb8.

\section{INTRODUCTION}

Foundation species strongly control ecosystem dynamics and functioning through their enhancement of habitat complexity, reduction of physical stress and modulation of resource availability (Dayton 1972). They often engage in mutualisms upon which the foundation species critically depend, for instance, for provision of essential resources or amelioration of chemical stressors (Dayton 1972; Stachowicz 2001; Kiers and others 2010; van der Heide and others 2012; Angelini and others 2016). Well-known examples of mutualisms involving foundation species are the reciprocal positive interactions between mangroves and sponges (Ellison and others 1996), seagrasses and lucinid clams (van der Heide and others 2012), and frugivores and Neotropical tree species (Peres and others 2016).

Although mutualists can be indirectly vital to ecosystem functioning by providing essential support to a foundation species (Loya and others 2001; Angelini and others 2016; de Fouw and others 2016; Peres and others 2016), their role can also be of direct importance when the mutualist is also a foundation species and thus strongly facilitates associated species. In these cases, the foundation species partners co-create a complex and low-stress habitat that is suitable for many different species, resulting in increased species richness and abundance (Thomsen and others 2010; Bishop and others 2013; Angelini and Silliman 2014; Bell and others 2014; Angelini and others 2015). Indeed, in many ecosystems, biodiversity and community structure seem not to be controlled by a single foundation species, but rather by a hierarchically organized assemblage of primary and secondary foundation species, as is for instance the case in tree-epiphyte ecosystems (Altieri and others 2007; Bishop and others 2012; Angelini and Silliman 2014; Thomsen and others 2018). However, how the increased abundances of facilitated species feed back to influence the growth and persistence of foundation species is not well understood.

In southeastern US salt marshes, the two foundation species Spartina alterniflora (hereafter cordgrass) and Geukensia demissa (hereafter mussels) engage in a mutualism of frequent occurrence in higher elevation marsh platforms (Angelini and others 2015, 2016; Bertness and others 2015; Derksen-Hooijberg and others 2018). The mutualism is facultative, meaning that these filter-feeding mussels and cordgrass can survive on their own, but both benefit from growing in association. Cordgrass is a C-4 grass that forms expansive monocultures and functions as a primary foundation species, as the base of its stems provide attachment substrate among which mussels form clumped aggregations (Bertness and Grosholz 1985). Besides providing substrate, cordgrass also facilitates mussel growth, survival and recruitment by increasing food availability and by ameliorating solar stress (Stiven and Kuenzler 1979; Bertness 1984; Altieri and others 2007; Angelini and others 2015; Derksen-Hooijberg and others 2018). The interaction between mussels and cordgrass is considered mutualistic, as mussels in turn facilitate cordgrass growth, clonal expansion and survival by enhancing nutrient availability, increasing water infiltration and holding capacity, and decreasing phytotoxic sulfide levels (Bertness and Miller 1984; Angelini and others 2015, 2016; Derksen-Hooijberg and others 2018). Moreover, mussels function as secondary foundation species, because they typically depend on the facilitation of cordgrass for their establishment and, once established, facilitate several invertebrate species by further enhancing habitat structure and complexity (Angelini and others 2015).

The spatial overlap between mussels and cordgrass in southeastern US salt marshes generates a habitat that is especially suitable for intertidal burrowing crabs. In particular, when mussels and cordgrass are both present the number of juvenile Uca pugnax (mud fiddler crab) are greatly increased (Angelini and others 2015). Studies that have investigated the effects of these sediment-filtering algivore and detritivore fiddler crabs on salt marsh plants and ecosystem functions thus far yield an ambivalent and possibly context-dependent picture. Some studies reported positive effects on cordgrass biomass that were attributed to crab-induced nutrient enrichment and/or soil oxygenation (Bertness 1985; Holdredge and others 2010), whereas others report negative effects on cordgrass seedling recruitment in sites where cordgrass has died back, and on marsh organic matter accumu- 
lation due to crab bioturbation (Thomas and Blum 2010; Smith and Tyrrell 2012). To date, however, it is unknown to what extent crabs interact with the cordgrass-mussel mutualism. Because this mutualism has been demonstrated to strongly augment cordgrass resilience and recovery after disturbances (Bertness and Miller 1984; Angelini and others 2015; Bertness and others 2015; Derksen-Hooijberg and others 2018), it is important to elucidate any factors that might alter the nature of this interaction.

We therefore conducted a full-factorial field experiment in a bare, former dieback site of a southeastern US salt marsh, and created plots with and without cordgrass, mussels and resident crabs to elucidate the direction and magnitude of crab effects on mussels, cordgrass and their interaction. Sixteen months into the experiment, we simulated a disturbance event by clipping all aboveground cordgrass biomass and removing all mussels, after which we monitored shoot regrowth after 10 days to investigate how crabs, mussels and their interactions affect cordgrass resilience. Finally, to examine the generality of the experimental results and their broader implications for understanding the stability of this mutualism in salt marshes across the southeastern US seaboard, we conducted a field survey across five salt marshes distributed from Florida to North Carolina, in which we correlatively examined the relations between cordgrass, mussels and crabs.

\section{METHODS}

\section{Study Site}

For the experiment, we selected a higher elevation marsh platform located in the National Estuarine Research Reserve on Sapelo Island, Georgia, USA (latitude $31.4074917^{\circ}$, longitude $-81.2898760^{\circ}$ ). These upper marsh areas are dominated by a shortform cordgrass that is generally nitrogen-limited in these areas (Mendelssohn 1979; Ornes and Kaplan 1989; Silliman and Zieman 2001).

In this marsh platform, mussels occur scattered, but frequently in aggregations ("mussel mounds") composed of 5-70 individuals (Derksen-Hooijberg and others 2018). Ribbed mussels filter phytoplankton and suspended detritus during high tide and deposit nutrient-rich pseudofeces on the marsh surface, around the base of cordgrass stems.

Similar to marshes across the region, several crab species occur at this site: Sesarma reticulatum (purple marsh crab, an omnivore), Panopeus obesus (blackclaw mud crab, a predator and scavenger), Eurytium limonsum (white-claw mud crab, a predator and scavenger) and Uca pugnax (mud fiddler crab, an algivore and detritivore) (Angelini and others 2015). However, as over $95 \%$ of the total number of intertidal crabs $\left(\sim 5-150\right.$ individuals per $\mathrm{m}^{2}$ in our area) is comprised of mud fiddler crabs (Angelini and others 2015), the focus of the experiment and interpretation of our results was on this species specifically.

We selected a dieback site of approximately $2400 \mathrm{~m}^{2}$ within the high marsh platform that formed during a drought in 2012. At the start of the experiment in 2014, cordgrass bordering the dieback area was recolonizing and all transplants survived and grew well, indicating that the stressor that caused the dieback was no longer present. We specifically chose an area denuded by an earlier extreme event because the site should in principle support all three species, but at the same time also allow us to cross presence/absence of all three species involved to unravel their interactions. Also, it was important to exclude any potential for competition and/or interference between cordgrass transplants and vegetation already present. We conducted a full-factorial field experiment in which the presence or absence of cordgrass, mussels and crabs were manipulated $(N=12$ replicates of 8 treatments, total of 96 plots), between April 2013 and August 2014.

\section{Experimental Set-Up}

We carried out a full-factorial experiment in which we assigned presence/absence of cordgrass and mussels, and ambient/reduced numbers of crabs as factors. In April 2013, cordgrass transplants standardized to 14-16 shoots, $25 \mathrm{~cm}$ diameter and $15 \mathrm{~cm}$ depth were transplanted from an adjacent healthy marsh area into the dieback site. In plots without cordgrass, we transplanted bare soil cores of the same size from an adjacent dieback site. In each mussel plot, we transplanted 20 mussels (3 mussels of $30-40 \mathrm{~mm}, 2$ of $40-50 \mathrm{~mm}, 3$ of 50 $60 \mathrm{~mm}, 6$ of $60-70 \mathrm{~mm}$ and 6 of $70-80 \mathrm{~mm}$ length), representing an aggregation size known to augment fiddler crab abundance (Angelini and others 2015) and size distribution that simulated natural mussel distributions (Derksen-Hooijberg and others 2018). Prior to transplantation, mussels were measured and tagged with shellfish tags (Hallprint, Australia).

In previous studies, fiddler crabs have been excluded from plots using exclosures (Bertness 1985; Nomann and Pennings 1998; Holdredge and others 2010). However, due to the relatively large mesh 
size $(>1 \mathrm{~cm})$ needed to prevent excess shading or sediment deposition artifacts, exclosure experiments typically exclude adult fiddler crabs and fail to exclude smaller juvenile crabs $(<0.5 \mathrm{~cm}$ carapace width). Although the exclusion cage approach may suffice in experiments where the contribution of juvenile fiddler crabs is negligible, the majority of crabs observed on mussel mounds in our system were juvenile mud fiddler crabs. To bypass the limitations and artifacts arising from the use of cages with fine mesh, we reduced benthic crustacean densities by spraying the plots with a solution of $\operatorname{Sevin}^{\circledR}\left(\right.$ Gardentech $^{\circledR}$, USA) containing $22.5 \%$ carbaryl (1-naphthyl- $N$-methylcarbamate) (permit: GCE-43-2013). Carbaryl is applied as an insecticide in home gardens and commercial farms, and has been used to control burrowing shrimp pests in oyster aquaculture since the early 1960s. It affects the nervous system, causing mortality in shrimps and crabs, whereas bivalves are relatively insensitive (Mayer 1987; Feldman and others 2000), hence its usage on oyster beds. Moreover, carbaryl is considered to have no lasting adverse effects on aquatic flora growth (Feldman and others 2000) and has recently been used to reduce the densities of small invertebrates in several scientific studies in algal mats (Poore and others 2009) and seagrass beds (Dumbauld and Wyllie-Echeverria 2003; Whalen and others 2013).

We conducted trials to determine the minimum spraying dosage needed to effectively reduce the number of fiddler crabs. On a typical spraying day, we found that spraying of 11 of a $1.3 \%$ dilution of Sevin divided over the 48 crab exclusion plots was effective in reducing juvenile fiddler crab density by $81 \%$. Plots were inspected regularly and were sprayed as soon as new crab burrows appeared, resulting in a spraying frequency of 1-2 times a week, depending on the weather and tidal conditions. Environmental degradation of carbaryl is relatively rapid. Above $\mathrm{pH} \mathrm{7,} \mathrm{carbaryl} \mathrm{is} \mathrm{mainly}$ degraded through hydrolysis and has a half-life in sterile seawater of approximately a day (Armbrust and Crosby 1991; Xu 2000). Plots were therefore only sprayed during low tide to maximize carbaryl concentrations when it contacted crabs, and to minimize the unintentional targeting of swimming crustacean species potentially migrating into the plots at high tides. We quantified crab abundance in all plots by counting all juvenile and adult fiddler crab burrows according to Angelini and others (2015) within plots in October 2013 and August 2014 and averaged the crab burrow densities recorded at these time points. The carbaryl treatment was effective in reducing juvenile fiddler crab density by $81 \%$ on average from 290 to 56 burrows $\mathrm{m}^{2}$ in crab removal compared to control plots $\left(\chi^{2}=-13.60 ; p<0.001\right.$; Figure 1A), and reduced adult fiddler density by $55 \%$ from 34 to 15 burrows $\mathrm{m}^{2}\left(\chi^{2}=-3.83 ; p<0.001\right.$; Figure 1B). Carbaryl had no effect on snail densities (on average 1 snail per plot, density of 20 snails $\mathrm{m}^{-2}, \chi^{2}=0 ; p=0.999$ )

\section{Cordgrass and Crab Effects on Mussels}

To assess the effects of cordgrass and crabs on mussels, we investigated mussel survival, growth and recruitment. After 16 months, all tagged mussels and recruits were collected from the plots, washed, measured and categorized as live, missing or dead in August 2014. As mussel growth rate declines with increasing size, we fitted mussel growth rates by means of the Von Bertalanffy growth curve (von Bertalanffy 1938) to compare mussel growth rates across different initial sizes. We calculated the growth constant $k\left(\mathrm{y}^{-1}\right)$ for each individual mussel as described by Derksen-Hooijberg and others (2018).

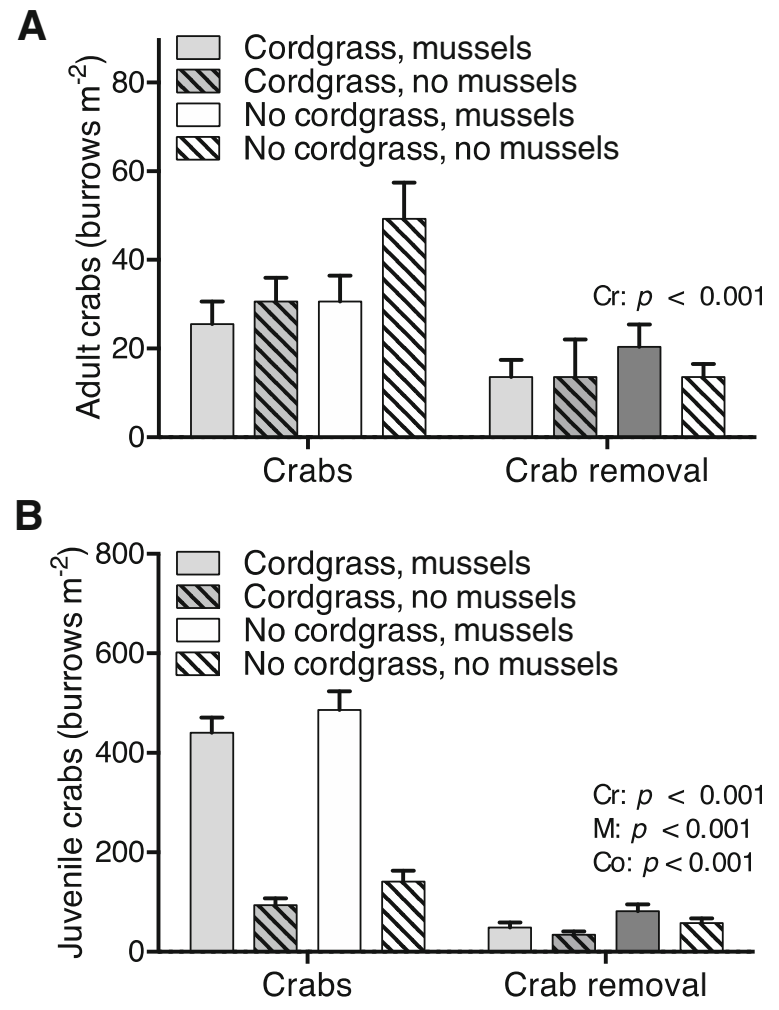

Figure 1. A Juvenile and adult crab abundance in plots with and without mussels, cordgrass and crab exclusion. B Mussel shell growth expressed in growth constant $k$ $\left(\mathrm{y}^{-1}\right)$. Cr, $\mathrm{M}$ and Co represent main effects of crabs, mussels, cordgrass and their interactions, respectively. Error bars represent + SE . 


\section{Mussel and Crab Effects on Cordgrass}

To assess the effects of mussels and crabs on cordgrass, we investigated cordgrass above- and belowground biomass, the chemical composition of cordgrass shoots, and the ability of cordgrass to withstand a physical disturbance. First, aboveground cordgrass biomass in all plots was clipped, collected and washed. Then, we quantified belowground biomass by taking four cores $(4 \mathrm{~cm}$ diameter) at each plot at four depth intervals: $0-5 \mathrm{~cm}$, $5-10 \mathrm{~cm}, 10-15 \mathrm{~cm}$ and $15-20 \mathrm{~cm}$ below the marsh surface. In mussel plots, an extra depth interval was taken from the pseudofeces layer, which accrues on the marsh surface. Belowground biomass was washed, and live tissue was separated from the dead fraction by testing flotation and by assessing texture and color (living roots have a firmer texture and white coloration). Finally, we tested cordgrass resilience by simulating a physical disturbance in August 2014: clipping all aboveground biomass and harvesting all mussels. We monitored the number of new emerging shoots 10 days after this event to measure cordgrass' ability to cope with the disturbance.

After harvesting, above- and belowground biomass was oven-dried at $60^{\circ} \mathrm{C}$ for at least $48 \mathrm{~h}$, until no subsequent weight loss occurred and then weighed. Belowground biomass weights were analyzed separately for each sampling depth and finally summed across all depths for total biomass analyses. A subsample of the shoots was ground and subsequently digested in $4 \mathrm{ml} \mathrm{HNO}_{3}(65 \%)$ and $1 \mathrm{ml} \mathrm{H}_{2} \mathrm{O}_{2}(30 \%)$ in a digestion microwave (Milestone type MLS 1200, Sorisole Lombardy, Italy). Digested samples were measured on an inductively coupled plasma optical emission spectrophotometer (ICP-OES, model Iris Intrepid II; Thermo Fisher Scientific, Waltham, MA, USA) to estimate sulfur and phosphorus concentrations. In addition, shoot carbon and nitrogen percentages were measured on an elemental analyzer (Carlo Erba NA1500, Thermo Fisher Scientific, Waltham, MA, USA).

\section{Cordgrass, Mussel and Crab Effects on Porewater}

After the first growth season, porewater was anaerobically collected in the upper $5 \mathrm{~cm}$ of the sediment of each plot with $5 \mathrm{~cm}$ rhizon soil moisture samplers (Rhizosphere Research Products, The Netherlands) connected to vacuumed $60-\mathrm{ml}$ syringes. Total sulfide concentrations were measured within $6 \mathrm{~h}$ of sample collection by fixating part of each sample with sulfide anti-oxidant buffer solution (SAOB) (HI4015-00, Hanna Instruments, USA) and measuring with a sulfide combination electrode (HI41 15, Hanna Instruments, USA). Prior to further analysis, another subsample of each plot was stored at $-20^{\circ} \mathrm{C}$ before being analyzed for $\mathrm{NO}_{3}{ }^{-}, \mathrm{NH}_{4}{ }^{+}$and $\mathrm{PO}_{4}{ }^{3-}$ concentrations on Auto Analyzer III systems (Bran and Luebbe, Norderstedt, Germany).

\section{Field Survey}

To assess the generality of interactions between fiddler crabs and the cordgrass-mussel mutualism, we conducted a survey in five salt marshes in the southeastern US covering $700 \mathrm{~km}$ of coastline in July and August 2015. Specifically, we visited five higher elevation marsh platforms dominated by short-form cordgrass that harbored mussel aggregations: in Florida (Guana Tolomato Matanzas National Estuarine Research Reserve (NERR): Latitude $30.0116667^{\circ}$, Longitude $-81.4925000^{\circ}$ ), Georgia (Jekyll Island: 31.0908333,-81 . $4888889^{\circ}$ and Sapelo Island NERR, 31.4072222 ${ }^{\circ}$, $-81.2900000^{\circ}$ ), South Carolina (ACE Basin NERR: SC, $\left.32.6963889^{\circ},-80.4286111^{\circ}\right)$ and North Carolina, Hoop Pole Creek (North Carolina, $\left.34.1302778^{\circ},-77.8547222^{\circ}\right)$. At each site, we haphazardly selected 7 cordgrass plots $\left(0.049 \mathrm{~m}^{2}\right)$ with mussel aggregations, and 7 adjacent cordgrass plots without mussels. In these plots, we recorded the number of mussels and the number of fiddler crab burrows. Finally, we collected cordgrass aboveground biomass from each plot, and then washed and oven-dried these samples for at least $48 \mathrm{~h}$ at $60^{\circ} \mathrm{C}$ (until no subsequent weight loss occurred) and weighed samples of each plot.

\section{Data Analyses}

Data were analyzed with $\mathrm{R}$ version 3.1.2 ( $\mathrm{R}$ Development Core Team). To assess main effects and interactive effects of cordgrass, mussels and fiddler crabs, two-way and three-way factorial ANOVAs were conducted, where the presence or absence of crabs, cordgrass and mussels were assigned as individual factors in a full-factorial design. Prior to data analyses, assumptions were checked for heterogeneity of variances and normality of the residuals. If assumptions were violated as was the case for belowground biomass, cordgrass leaf $\mathrm{P}$, cordgrass leaf $\mathrm{N}$, and porewater $\mathrm{PO}_{4}$, data were Box-Cox transformed. Data on sulfide concentrations in porewater did not sufficiently meet both assumptions after Box-Cox transformation and was therefore analyzed with a nonparametric Mann- 
Whitney $U$ test. The effects of crabs, mussels and cordgrass on count data were analyzed with a Poisson distribution (lme4 package in R), or, if overdispersion was found, with a negative binomial model. Correlations from the field survey data were tested with Pearson's correlation coefficient and linear regression models. We report all significant factors and their interactions in the results, and provide a complete statistics summary in Supplementary Table 1.

\section{Results}

\section{Crab Abundance}

In our experimental manipulation, adult fiddler crab burrow density was low ( 34 burrows $\mathrm{m}^{-2}$ ) and not affected by cordgrass presence or mussel addition $\left(\chi^{2}=-1.30 ; p=0.19\right.$ and $\chi^{2}=0.31 ; p=0.76$; Figure 1A). Mussel addition strongly increased juvenile crab burrow density from 117 to 463 burrows $\mathrm{m}^{-2}\left(\chi^{2}=-8.11 ; p<0.001\right.$, Figure 1B). Juvenile crab burrow density was also slightly lower in cordgrass plots compared to no-cordgrass (8 vs. 9 burrows; $\left(\chi^{2}=-3.58 ; p<0.001\right)$, potentially due to measurement bias caused by lower burrow visibility in vegetated plots.

\section{Cordgrass and Crab Effects on Mussels}

Crab removal and cordgrass presence both enhanced mussel growth, expressed by its relative growth constant $k\left(\mathrm{y}^{-1}\right) \quad\left(15 \%, \quad \mathrm{~F}_{1,44}=81.19\right.$; $p<0.001$ and $31 \%, \mathrm{~F}_{1,44}=76.68 ; p<0.001$, respectively, Figure 2). Specifically, crab removal effects were most pronounced in cordgrass plots (interaction $\mathrm{F}_{1,44}=7.10 ; p=0.01$ ); in other words, the growth-diminishing effect of crabs on mussels was larger in cordgrass ( $17 \%$ reduction in $k$ ) than

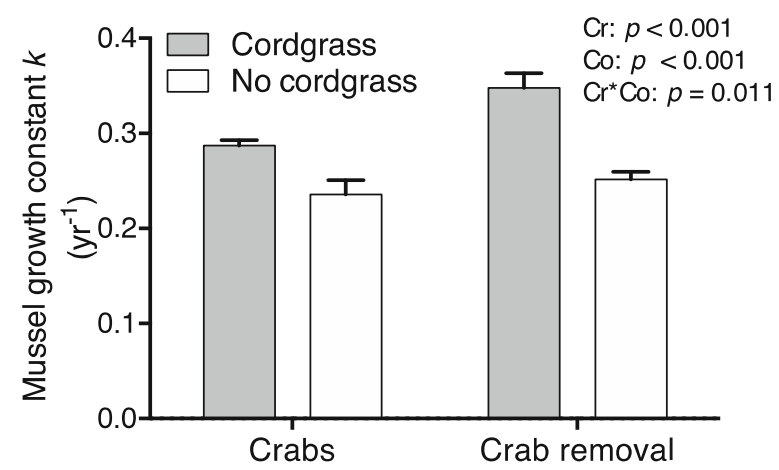

Figure 2. Mussel shell growth expressed in growth constant $k\left(\mathrm{y}^{-1}\right)$. Cr and Co represent main effects of crabs and cordgrass and their interactions, respectively. Error bars represent $+\mathrm{SE}$. in no-cordgrass $(6 \%$ reduction) plots. We did not detect a significant effect of crabs on the number of mussel recruits $\left(\chi^{2}=1.04 ; p=0.30\right)$, or on mussel survival $\left(\chi^{2}=1.63 ; p=0.10\right)$.

\section{Mussel and Crab Effects on Cordgrass}

Aboveground cordgrass biomass nearly doubled in mussel addition plots (119 vs. $237 \mathrm{~g} \mathrm{~m}^{-2}$; $\mathrm{F}_{1,44}=21.10 ; p<0.001$, Figure $3 \mathrm{~A}$ ) and was significantly lower in crab plots $\left(\mathrm{F}_{1,44}=8.73\right.$; $p<0.001)$. However, the effects of crabs strongly depended on mussel treatment, while crab presence reduced cordgrass biomass by $51 \%$ in mussel addition plots ( 317 vs. $156 \mathrm{~g} \mathrm{~m}^{-2}$ ), crab presence had little effect on biomass in no-mussel plots (114 vs. $124 \mathrm{~g} \mathrm{~m}^{-2}$; interaction $\mathrm{F}_{1,44}=11.08 ; p=0.002$, Figure $3 \mathrm{~A}$ ). Similarly, belowground biomass was enhanced by mussels $\left(50\right.$ vs. $91 \mathrm{~g} \mathrm{~m}^{-2}$; $\mathrm{F}_{1,44}=13.18 ; p<0.001$ ), and decreased by crabs $\left(\mathrm{F}_{1,44}=11.23 ; p=0.002\right)$, and these two factors interacted such that crabs negatively affected cordgrass more in mussel than non-mussel plots (54 vs. $46 \mathrm{~g} \mathrm{~m}^{-2}$ in no-mussel plots; 57 vs. $124 \mathrm{~g} \mathrm{~m}^{-2}$ in mussel plots, $\mathrm{F}_{1,44}=7.01 ; \mathrm{p}=0.01$; Figure $3 \mathrm{~A})$. Furthermore, we found that $95 \%$ of the total root and rhizome biomass was located in the top $15 \mathrm{~cm}$ of the sediment in all treatments, and that the negative effects of crabs in mussel plots were evenly distributed over this depth (Figure $3 \mathrm{~B})$.

\section{Mussel and Crab Effects on Cordgrass Resilience}

Mussel addition strongly stimulated cordgrass resilience to disturbance, tested by clipping aboveground biomass and removing all mussels. The survival of cordgrass shoots was enhanced by mussels on each plot (survival rate 0.96 vs. 0.5, meaning cordgrass shoots re-emerged in 96 vs. $50 \%$ of the plots $\left(\chi^{2}=10.36 ; p=0.001\right)$ as well as shoot regrowth (13 vs. 1 newly emerging shoots, $\left(\chi^{2}=-9.00 ; p<0.001\right)$, but the latter effect was significantly reduced in the presence of crabs (mussel by crab interaction, $\left(\chi^{2}=-2.33\right.$; $p=0.020$, Figure 3C). Specifically, while crab removal had no effect on cordgrass regrowth in nomussel plots ( 1 shoot), it more than tripled the positive effect of mussels on regrowth (6 vs. 19 shoots), indicating that crabs diminish the positive effects of mussels on cordgrass shoot regrowth. 

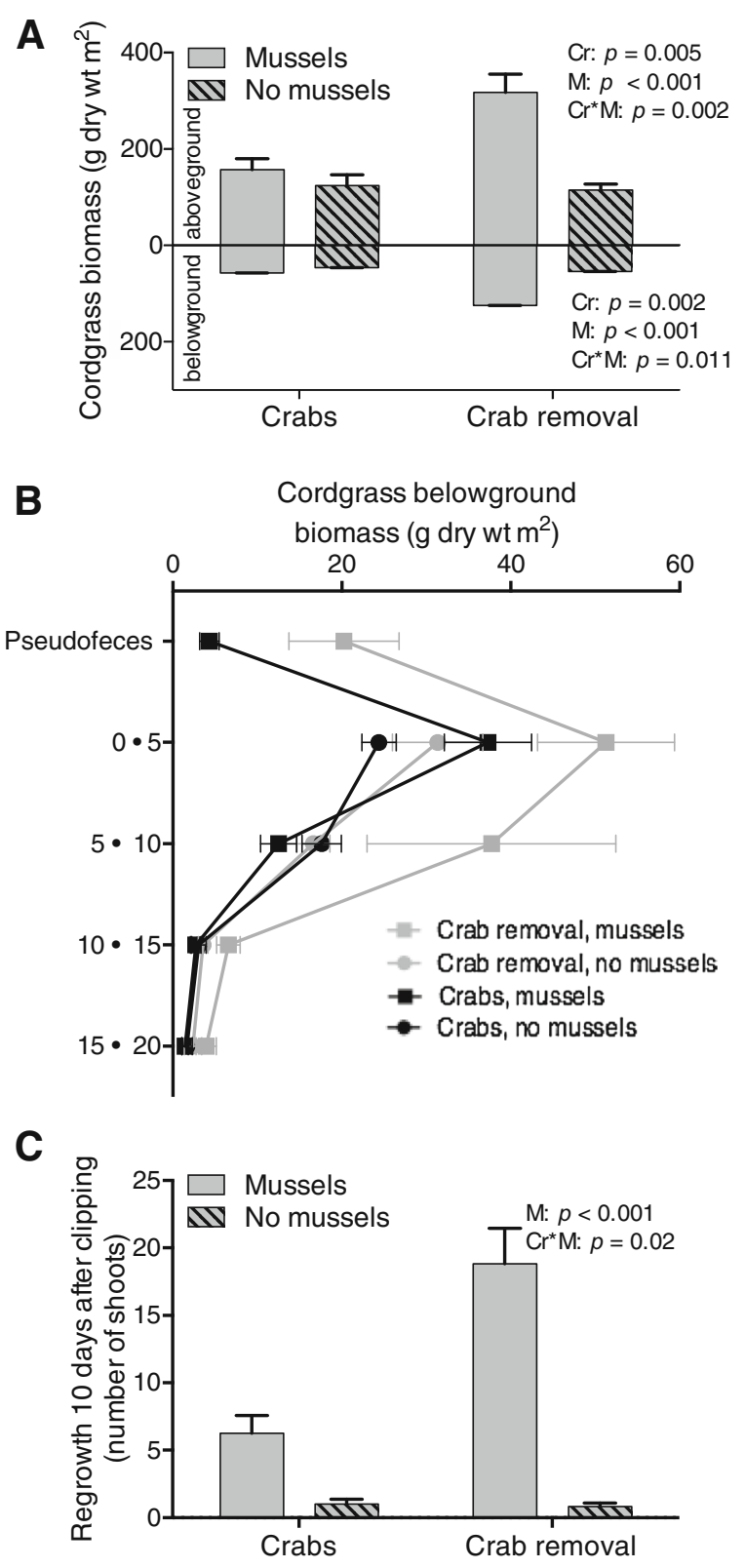

Figure 3. A Cordgrass biomass. B Cordgrass belowground biomass across $5 \mathrm{~cm}$ depth intervals. c) Cordgrass shoot regrowth 10 days after the simulated disturbance. $\mathrm{Cr}, \mathrm{M}$ and Co represent main effects of crabs, mussels, cordgrass and their interactions, respectively. Error bars represent $+\mathrm{SE}$.

\section{Treatment Effects on the Abiotic Environment and Plant Chemistry}

Porewater ammonium $\left(\mathrm{NH}_{4}{ }^{+}\right)$concentrations were $97 \%$ lower in cordgrass compared to no-cordgrass plots ( 8 vs. $283 \mu \mathrm{M} ; \mathrm{F}_{1,88}=652.43 ; p<0.001$ ) and 1.6-times higher in mussel compared to no-mussel plots (178 vs. $\left.113 \mu \mathrm{M} ; \mathrm{F}_{1,88}=22.39 ; p<0.001\right)$. Crab presence interacted with cordgrass presence, such that the ammonium-reducing effect of crabs was more pronounced in bare plots $\left(\mathrm{F}_{1,88}=14.54\right.$; $p<0.001$; Figure 4A), presumably because cordgrass obscured the crab effect by taking up nearly all $\mathrm{NH}_{4}{ }^{+}$. We did not detect $\mathrm{NO}_{3}{ }^{-}$in porewater. The effects of mussels and crabs on porewater nitrogen $(\mathrm{N})$ availability were also visible in the $\mathrm{N}$ content of cordgrass shoots. Mussels enhanced leaf $\mathrm{N}$ content by $15 \% \quad\left(\mathrm{~F}_{1.44}=11.60 ; p=0.001\right.$, Figure $\left.4 \mathrm{~B}\right)$, while crabs decreased it by $9 \% \quad\left(\mathrm{~F}_{1,44}=6.31\right.$; $p=0.016$ ).

Cordgrass reduced porewater phosphate $\left(\mathrm{PO}_{4}{ }^{3-}\right)$ concentrations by $36 \% \quad\left(\mathrm{~F}_{1,88}=4.34 ; p=0.040\right)$ and mussels enhanced phosphate by $63 \%$ $\left(\mathrm{F}_{1,88}=6.31 ; p=0.014\right)$, whereas crabs had no effect $\left(\mathrm{F}_{1,88}=0.040 ; p=0.841\right.$, Figure $\left.4 \mathrm{C}\right)$. In the plant shoot tissue, mussels increased $\mathrm{P}$ content by $15 \%\left(\mathrm{~F}_{1,44}=15.15 ; p=0.001\right)$, whereas crabs decreased $\mathrm{P}$ content $\left(\mathrm{F}_{1,44}=10.51 ; p=0.002\right)$. However, the latter effect depended on the mussel treatment: crabs had no effect in no-mussel plots ( 38 vs. $37 \mu \mathrm{mol} \mathrm{g}^{-1}$ ), but reduced $\mathrm{P}$ content by $19 \%$ in mussel plots (48 vs. $39 \mu \mathrm{mol} \mathrm{g}{ }^{-1}$, interaction effect $\mathrm{F}_{1,44}=8.27 ; p=0.006$, Figure 4D). Porewater sulfide concentrations were 193\% higher in cordgrass plots $(666$ vs. $227 \mu \mathrm{M}$; $\left.\mathrm{F}_{1,88}=3.16 ; p=0.002\right)$, and $80 \%$ lower in mussel addition plots $\left(149\right.$ vs. $745 \mu \mathrm{M} ; \mathrm{F}_{1,88}=-4.90$; $p<0.001)$. Highest sulfide concentrations were found in cordgrass treatments where mussels were absent, as the plants stimulate accumulation of organic matter, which is then decomposed by sulfate-reducing bacteria that generate sulfide as a byproduct, while mussels decrease sulfide through multiple mechanisms (see discussion). We did not find any significant effect of crab treatment $\left(\mathrm{F}_{1,88}=1.47 ; p=0.143\right.$; Figure $\left.4 \mathrm{E}\right)$.

\section{Field Survey}

In our field survey, crab abundance was higher in mussel mounds in all five investigated salt marshes, as indicated by the number of burrows that were nearly absent in plots without mussels ( 327 vs. 20 burrows $\mathrm{m}^{-2} ; \chi^{2}=82.28 ; p<0001$; Figure 5A). The number of crab burrows in mussel aggregations differed per salt marsh site, but was near constant and low in cordgrass plots without mussels, illustrated by a main effect of site and a significant interaction between site and mussel presence $\left[\left(\chi^{2}=217.10 ; \quad p<0.001\right)\right.$ and $\left(\chi^{2}=36.73\right.$; $p<0.001)]$. Furthermore, we found that live aboveground cordgrass biomass was on average $67 \%$ higher on mussel mounds ( 391 vs. $234 \mathrm{~g} \mathrm{~m}^{-2}$; $\mathrm{F}_{1,60}=22.97 ; p<0.001$; Figure $\left.5 \mathrm{~B}\right)$, but that the 

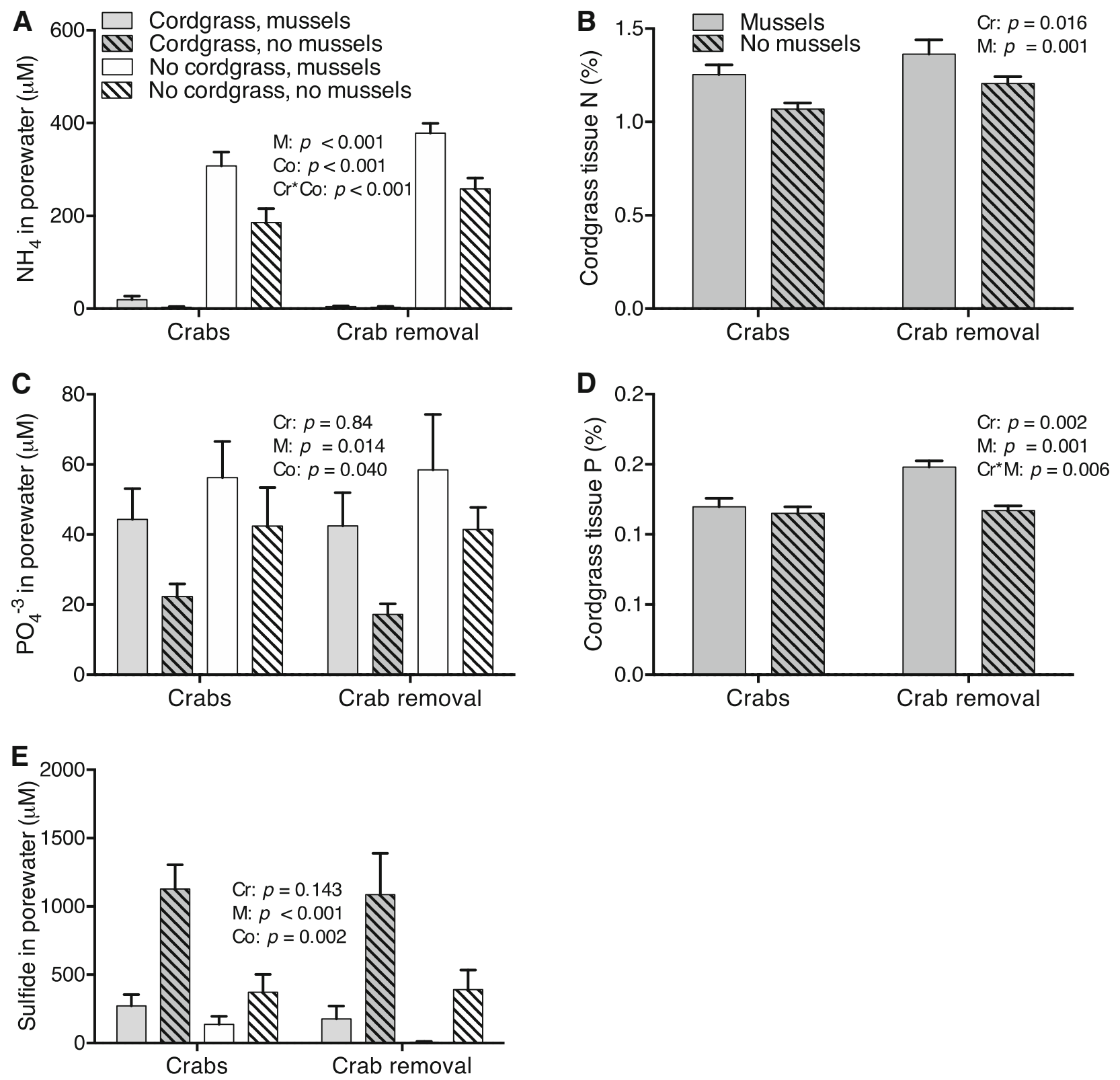

Figure 4. A, C, E $\mathrm{NH}_{4}{ }^{+}, \mathrm{PO}_{4}^{-3}$ and sulfide concentrations in the porewater of the top $5 \mathrm{~cm}$ of the sediment. B, D Percentage $\mathrm{N}$, and $\mathrm{P}$ concentrations in cordgrass shoots. Cr, M and Co represent main effects of crabs, mussels, cordgrass and their interactions, respectively. Error bars represent + SE.

effect size differed between marsh sites $\left(\mathrm{F}_{4,60}=6.47 ; p<0.001\right)$. Linear regression revealed a significant positive correlation between the number of mussels in an aggregation and the number of fiddler crab burrows $(r=0.48$; $\mathrm{F}_{1,33}=7.39 p=0.010$; Figure $5 \mathrm{C}$ ), and a significant negative correlation between the number of burrows and aboveground cordgrass biomass $(r=$ $-0.43 ; \mathrm{F}_{1,33}=7.40 ; p=0.010$; Figure 5D).

\section{Discussion}

Although the community of many ecosystems appears to be facilitated by a hierarchical assemblage of primary and secondary foundation species (Altieri and others 2007; Bishop and others 2012; Angelini and Silliman 2014; Thomsen and others 2018), there is little understanding of how high densities of facilitated species reciprocally affect the growth and persistence of the foundation species. In this paper, we show that facilitation of the community can feed back to negatively affect the 

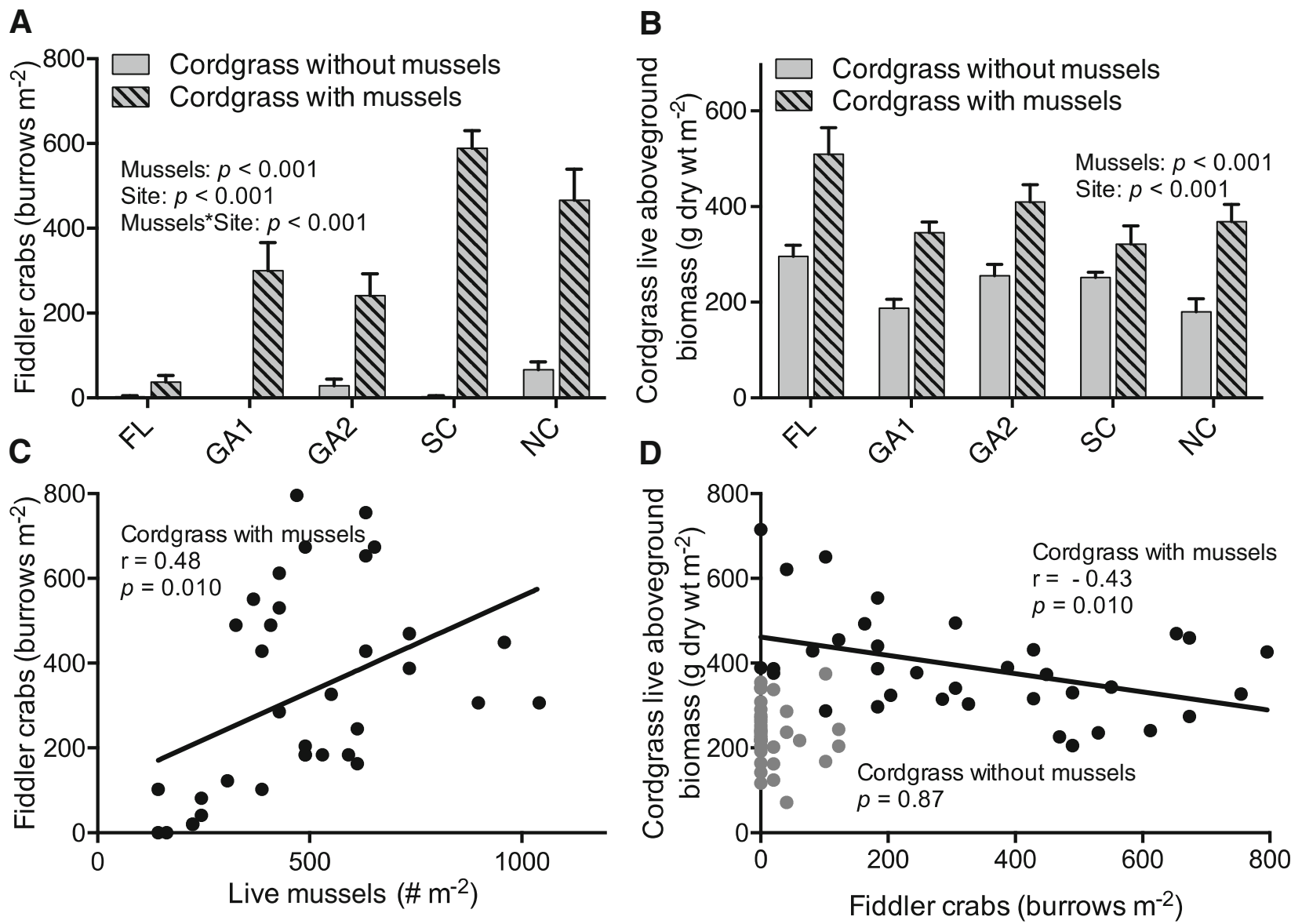

Figure 5. A, B Number of fiddler crab burrows $(\mathbf{A})$ and cordgrass live aboveground biomass (B) in five southeastern US marshes in cordgrass stands with and without mussel aggregations. Error bars represent + SE. C, D Correlations of five marshes combined: the number of life mussels in an aggregation and the number of fiddler crab burrows in cordgrass stands $(\mathbf{C})$ and fiddler crab burrows and cordgrass live aboveground biomass (D). Mussels and site represent main effects of mussels, salt marsh site, and their interaction, respectively; $r$ represents Pearson's correlation coefficient.

foundation species, thereby potentially dampening their ecosystem-structuring effects. Specifically, we demonstrate that the ecosystem resilience- and recovery-enhancing mutualism between mussels and cordgrass in southeastern US salt marshes (Bertness and others 2015; Angelini and others 2016; Derksen-Hooijberg and others 2018) is dampened by fiddler crabs that themselves profit from the positive cordgrass-mussel interaction. Indeed, in our experiment, mussels strongly increased cordgrass biomass. The overlap of these habitat-forming species, however, also consistently supported high densities of associated fiddler crabs. These crabs, in turn, reduced both cordgrass and, to a lesser extent, mussel growth and diminished the ability of cordgrass to survive and re-sprout post disturbance. These experimental results were supported by the field survey, which consistently showed enhanced cordgrass biomass and crab abundance in mussel mounds, and a negative cor- relation between cordgrass biomass and crab abundance.

\section{Mechanisms by Which Crabs Interfere with the Mutualism}

We detail three potential mechanisms through which the high numbers of fiddler crabs can interfere with the mutualism between cordgrass and mussels (illustrated in Figure 6A, B). First, crabs may reduce the availability of $\mathrm{N}$ in sediment porewater, thereby significantly reducing the $\mathrm{N}$ content in cordgrass shoots (Figure 6B) and likely limiting cordgrass' growth (Mendelssohn 1979; Cavalieri and Huang 1980; Ornes and Kaplan 1989; Silliman and Zieman 2001). A potential explanation for these effects could be that the high number of crab burrows on mussel mounds enhances oxygen intrusion into the sediment, thereby stimulating nitrification (Laverock and others 2011) 
[that is, microbial oxidation of ammonium $\left(\mathrm{NH}_{4}{ }^{+}\right)$ and nitrite $\left.\left(\mathrm{NO}_{2}{ }^{-}\right)\right]$and reducing the $\mathrm{NH}_{4}{ }^{+}$pool in porewater. However, we did not detect $\mathrm{NO}_{3}{ }^{-}$in any of our porewater samples and all sediments were anoxic as evidenced by high sulfide levels. Therefore, we suspect that, if nitrification was indeed enhanced by the crabs, denitrification rates must also have been increased, causing rapid conversion of any nitrate produced into gaseous nitrogen, which cannot be utilized by cordgrass. In addition, crab bioturbation and the increased sediment surface area created by the crab burrows may have facilitated the escape of this gaseous nitrogen to the atmosphere, and increased porewater ammonium diffusion into surrounding seawater (Aller 1988; Dollhopf and others 2005; Laverock and others 2011). As porewater ammonium levels are often significantly higher in dieback site soils relatively to healthy marsh areas (Sharp and Angelini 2016), it is likely that the effects of crabs on reducing $\mathrm{N}$ availability to cordgrass may be even more pronounced in non-die-off, or healthy, marsh areas, such as those where the regional surveys took place and negative association between crab density and cordgrass biomass were detected.

Second, crabs may damage cordgrass roots while maintaining their burrows (Figure 6B), particularly because $95 \%$ of cordgrass root biomass was located in the top $15 \mathrm{~cm}$ of sediment regardless of treatment, which coincides with the burrowing depth of mud fiddler crabs (Katz 1980). Earlier crab removal experiments in New England marshes revealed that although Uca sp. reduce cordgrass rhizome biomass and plant detrital debris in the top $0-10 \mathrm{~cm}$ of the soil through their burrowing activities, these crabs stimulate aboveground cordgrass growth likely by enhancing soil oxygen availability and marsh drainage (Bertness 1985). Similarly, Gittman and Keller (2013) found that fiddler crab bioturbation can facilitate cordgrass production in North Carolina marshes, when plants are also subjected to snail grazing, perhaps because of increased oxygenation and/or stimulated remineralization of organic matter. However, in each of these studies, the crab density appears to have been significantly lower $\left(22-75 \mathrm{crabs} / \mathrm{m}^{2}\right)$ compared to 468 fiddler burrows $/ \mathrm{m}^{2}$ on mussel mounds in our experiment. Collectively, these results suggest that the effects of crab bioturbation on cordgrass, and likely other marine foundation species that facilitate burrowing crabs [for example, Argentinean salt marshes (Martinetto and others 2016) and West African seagrass beds (van der Zee and others 2016)] are context-dependent such that crabs may facilitate cordgrass growth at low to intermediate densities, but hamper it at high densities where their rate of damaging roots outpaces the rate at which cordgrass can generate these critical tissues.

Third, we found that crabs reduced mussel growth. Although relatively minor compared to the positive effect of cordgrass $(+31 \%$ for cordgrass vs $-13 \%$ for crabs), this small but significant negative effect on mussel growth could result in cascading negative effects on cordgrass growth when crab numbers are very high. Although we did not directly test the underlying mechanism, we suggest
A Cordgrass-mussel mutualism

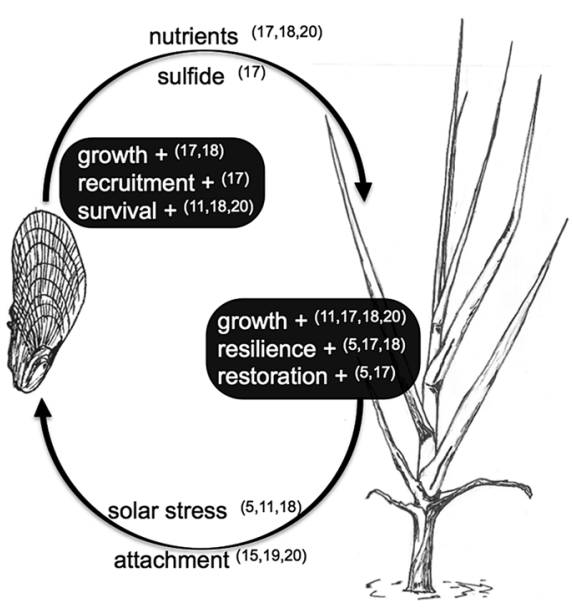

B Crab effects on mutualism

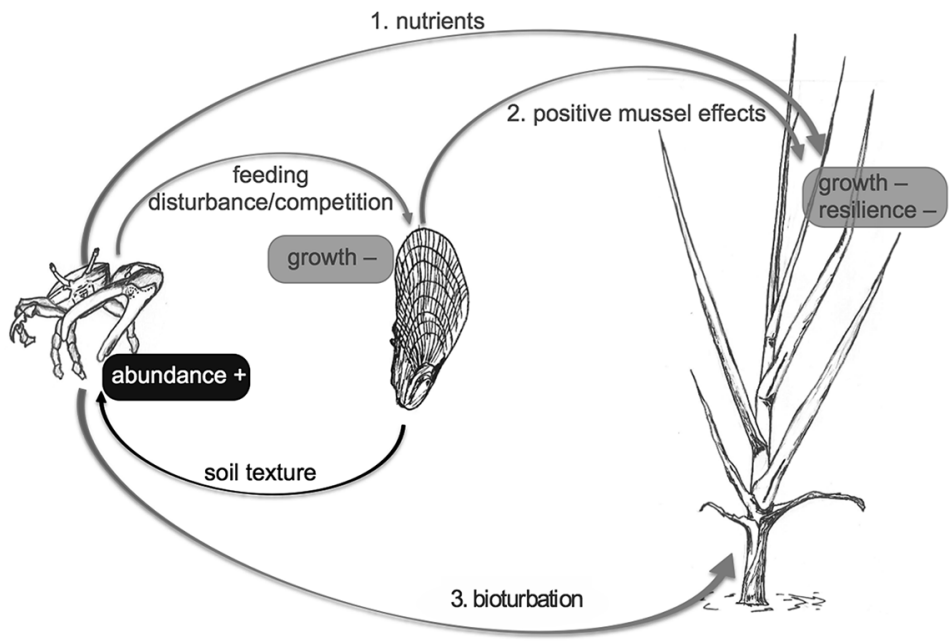

Figure 6. Proposed mechanistic pathways of $\mathbf{A}$ the cordgrass-mussel mutualism and $\mathbf{B}$ crab effects on mutualism. Black arrows and colorations depict beneficial effects, gray arrows and colorations depict negative effects. 
that crabs may compete with mussels of food-particularly resuspended benthic algae and organic particles. Mussels produce nutrient-rich pseudofeces that are deposited in and around their aggregations to form mounds that are rich in organic matter and on which benthic algae thrive (Angelini and others 2015). Fiddler crabs feed on this substrate and, in doing so, may reduce the biomass of benthic algae and detritus that can be resuspended during high tide and consumed by the mussels (Kreeger and Newell 2001). This hypothesis is also supported by our observations of algal mats forming and detrital debris accruing on the surface of the mussel mounds, but only in crab removal treatments. Finally, it may also be possible that the crabs simply interfere with ribbed mussels filter feeding, for instance by crawling on their shells or introducing cues that prompt mussels to stop feeding or by altering water flow patterns at the marsh surface (Robson and others 2010; Naddafi and others 2007). As ribbed mussel filtration rates are directly correlated with mussel weight (Riisgard 1988), the crab-mediated decrease in mussel growth may indirectly result in a decrease in the beneficial effects of mussels on cordgrass, such as nutrient enhancement and the lowering of phytotoxic sulfide (Bertness 1984; Angelini and others 2015, 2016; Derksen-Hooijberg and others 2018) (Figure 6B). The latter is suggested to take place via multiple mechanisms. Previous studies showed that mussels increase infiltration of oxygen-rich surface water by excreting pseudofeces, and that mussels increase porewater iron concentrations, which can bind sulfide and catalyze sulfide oxidation (Wilsey and others 1992; Angelini and others 2015; Derksen-Hooijberg and others 2018). Also, mussels may actively remove sulfide from the water layer as mussel gill mitochondria have been found to oxidize sulfide (Lee and others 1996).

Importantly, crab densities and their cascading negative effects on foundational cordgrass and mussels are held in check by several factors that likely stabilize the cordgrass-mussel-fiddler crab interaction and support the persistence of this system. In particular, intraspecific competition for benthic algae and detrital food resources, predation by nekton, benthic predators, raccoons and birds, and variation in recruitment can modulate crab densities (Teal 1958; Wolf and others 1975). Although the relatively importance of these factors in structuring crab populations can vary with latitude and across marsh elevations, they collectively keep populations low enough that their negative effects do not appear to overwhelm the foundation species and trigger their collapse.

\section{Implications}

Cordgrass-mussel-crab interactions occur naturally and widely in southeastern US salt marshes, and cordgrass growing on mussel mounds with high crab numbers consistently outperforms cordgrass outside the mounds. Our findings, however, demonstrate that crab interference of the cordgrass-mussel mutualism can reduce the performance of both mutualists, and may thus indirectly reduce ecosystem resilience as these negative effects compromise cordgrass' ability to re-sprout after being disturbed (Figure 3C). Similar dynamics have been observed in seagrass ecosystems, where drought has been shown to induce the breakdown of the facultative mutualism between seagrasses and lucinids, thereby accelerating ecosystem collapse (de Fouw and others 2016).

In contrast to the seagrass-lucinid mutualism, which has a more diffuse distribution, mussels form distinct clumped aggregations ranging from several to a few hundred individuals in southeastern US marsh platforms $[5,11]$. This distribution is thought to be maintained by positive intraspecific interactions in which neighboring mussels provide others a refuge from predation, and by competition for food and larval recruitment that limit aggregation size (Bertness and Grosholz 1985; Stiven and Gardner 1992; Nielsen and Franz 1995; Angelini and others 2015). The results from the current study suggest that the negative effects arising from the increase in fiddler crab density with mussel density may be another factor limiting mussel aggregation size and thus the distribution of the cordgrass-mussel mutualism in these systems. Whether facilitated species mediate the spatial configuration of foundation species' overlap in other systems is not known and may have important implications for ecosystem structure, function and stability.

Results from recent studies strongly advocate for the inclusion of mussels in saltmarsh conservation and restoration projects (Bertness and others 2015; Angelini and others 2016; Derksen-Hooijberg and others 2018). Although crabs clearly weaken the positive effect that the mutualism may have on restoration, we do not advocate any measures to exclude crabs for restoration purposes. First of all, this is because the crabs are a natural component of the system one aims to restore, and their negative effects do not overwhelm the overall positive effects of the mutualism. Specifically, we found that mussel stimulate cordgrass growth by $99 \%$, while cordgrass increases mussel growth by $31 \%$. By contrast, crabs decrease cordgrass and mussel 
growth by only 35 and $13 \%$, respectively. Moreover, no measures were taken to exclude crabs in the earlier studies, implying that the strong positive effects of the cordgrass mutualism on restoration yield were obtained in the presence of crabs. Secondly, although we successfully used carbaryl to unravel the interactions between cordgrass, mussels and crabs, we certainly do not advocate its large-scale use as it can affect all arthropods and may have indirect negative cascading effects, for instance on fish near oyster farms (Labenia and others 2007). Instead, we advise practitioners to use the obtained knowledge in a predictive sense; co-transplantation of mussels in cordgrass restoration (Derksen-Hooijberg and others 2018) may be even more successful in locations with lower natural fiddler crab abundance.

\section{Conclusions}

This study demonstrates that high densities of associated fiddler crabs facilitated by two overlapping mutualistic foundation species, negatively affected both species. By decreasing nutrient availability and mussel growth and potentially damaging cordgrass roots, fiddler crabs not only reduced the growth, but also decreased the resilience of the primary foundation species in this saltmarsh system. Foundation species similarly drive habitat structure and facilitate ecological communities in many other ecosystems, including coral reefs, seagrasses, mangroves, and forests (Angelini and others 2011). Moreover, the communities in these ecosystems are often facilitated by multiple, hierarchically organized primary and secondary foundation species, such as for example oysters growing on mangrove roots, or epiphytic plants growing in forest trees (Ellwood and Foster 2004; Altieri and others 2007; Bishop and others 2012; Angelini and others 2015). Hence, as the proliferation of species richness and abundance is common when foundation species overlap, we recommend deeper consideration of the hidden vulnerability of foundation species' to negative impacts of the species they facilitate in future research and conservation projects.

\section{ACKNOWLEDGEMENTS}

We thank Sean Sharp for assistance in the field; Caroline Reddy, Gracie Townsend, and Jacob Shalack for logistical assistance, and the Georgia Coastal Ecosystems Long-Term Ecological Research site and the Sapelo Island National Estuarine Research Reserve for their support.

\section{FUNDING}

Funds supporting this study were provided by NWO-VENI (863.12.003) awarded to T.v.d.H. and NSF-DEB (1546638) awarded to C.A.

\section{Compliance with Ethical Standards}

Conflict of interest The authors declare no competing interests.

\section{OPEN ACCESS}

This article is distributed under the terms of the Creative Commons Attribution 4.0 International License (http://creativecommons.org/licenses/by/4 $.0 /$ ), which permits unrestricted use, distribution, and reproduction in any medium, provided you give appropriate credit to the original author(s) and the source, provide a link to the Creative Commons license, and indicate if changes were made.

\section{REFERENCES}

Aller RC. 1988. Benthic fauna and biogeochemical processes in marine sediments: the role of burrowing structures. In: Blackburn TH, Sørensen J, Eds. Nitrogen cycling in coastal marine environments. New York: Wiley. p 301-38.

Altieri AH, Silliman BR, Bertness MD. 2007. Hierarchical organization via a facilitation cascade in intertidal cordgrass bed communities. Am Nat 169:195-206.

Angelini C, Altieri AH, Silliman BR, Bertness MD. 2011. Interactions amongFoundation Species and Their Consequences for Community Organization, Biodiversity, and Conservation. Bioscience 61:782-9.

Angelini C, Griffin JN, van de Koppel J, Lamers LPM, Smolders AJP, Derksen-Hooijberg M, van der Heide T, Silliman BR. 2016. A keystone mutualism underpins resilience of a coastal ecosystem to drought. Nat Commun 7:12473.

Angelini C, Silliman BR. 2014. Secondary foundation species as drivers of trophic and functional diversity: evidence from a tree epiphyte system. Ecology 95:185-96.

Angelini C, van der Heide T, Griffin JN, Morton JP, DerksenHooijberg M, Lamers LPM, Smolders AJP, Silliman BR. 2015. Foundation species' overlap enhances biodiversity and multifunctionality from the patch to landscape scale in southeastern United States salt marshes. Proc $\mathrm{R}$ Soc $\mathrm{B}$ 282:20150421

Armbrust KL, Crosby D. 1991. Fate of carbaryl, l-naphthol, and atrazine in seawater. Pac Sci 45:314-20.

Bell JE, Bishop MJ, Taylor RB, Williamson JE. 2014. Facilitation cascade maintains a kelp community. Mar Ecol Prog Ser 501:1-10.

Bertness MD. 1984. Ribbed mussels and Spartina alterniflora production in a New England salt marsh. Ecology 65:1794807.

Bertness MD. 1985. Fiddler crab regulation of Spartina alterniflora production on a New England salt marsh. Ecology 66:104255. 
Bertness MD, Brisson CP, Crotty SM. 2015. Indirect human impacts turn off reciprocal feedbacks and decrease ecosystem resilience. Oecologia 178:231-7.

Bertness MD, Grosholz E. 1985. Population dynamics of the ribbed mussel, Geukensia demissa: the costs and benefits of an aggregated distribution. Oecologia 67:192-204.

Bertness MD, Miller T. 1984. The distribution and dynamics of Uca pugnax (Smith) burrows in a New England salt marsh. J Exp Mar Biol Ecol 83:211-37.

Bishop MJ, Byers JE, Marcek BJ, Gribben PE. 2012. Densitydependent facilitation cascades determine epifaunal community structure in temperate Australian mangroves. Ecology 93:1388-401.

Bishop MJ, Fraser J, Gribben PE. 2013. Morphological traits and density of foundation species modulate a facilitation cascade in Australian mangroves. Ecology 94:1927-36.

Cavalieri AJ, Huang AHC. 1980. Accumulation of proline and glecinebetaine in Spartina alterniflora Loisel. In response to $\mathrm{NaCl}$ and nitrogen in the marsh. Oecologia 49:224-8.

Dayton PK. 1972. Toward an understanding of community resilience and the potential effects of enrichments to the benthos at McMurdo Sound, Antarctica. In Proceedings of the colloquium on conservation problems in Antarctica: Lawrence, Kansas, USA: Allen Press. pp 81-96.

de Fouw J, Govers LL, van de Koppel J, van Belzen J, Dorigo W, Cheikh MAS, Christianen MJ, van der Reijden KJ, van der Geest M, Piersma T. 2016. Drought, mutualism breakdown, and landscape-scale degradation of seagrass beds. Curr Biol 26:1051-6.

Derksen-Hooijberg M, Angelini C, Lamers LP, Borst A, Smolders A, Hoogveld JR, Paoli H, de Koppel J, Silliman BR, der Heide T. 2018. Mutualistic interactions amplify salt marsh restoration success. J Appl Ecol 55:405-14.

Dollhopf SL, Hyun J-H, Smith AC, Adams HJ, O'Brien S, Kostka JE. 2005. Quantification of ammonia-oxidizing bacteria and factors controlling nitrification in salt marsh sediments. Appl Environ Microbiol 71:240-6.

Dumbauld BR, Wyllie-Echeverria S. 2003. The influence of burrowing thalassinid shrimps on the distribution of intertidal seagrasses in Willapa Bay, Washington, USA. Aquat Bot 77:27-42.

Ellison AM, Farnsworth EJ, Twilley RR. 1996. Facultative mutualism between red mangroves and root-fouling sponges in Belizean Mangal. Ecology 77:2431-44.

Ellwood MDF, Foster WA. 2004. Doubling the estimate of invertebrate biomass in a rainforest canopy. Nature 429:54951.

Feldman KL, Armstrong DA, Dumbauld BR, DeWitt TH, Doty DC. 2000. Oysters, crabs, and burrowing shrimp: review of an environmental conflict over aquatic resources and pesticide use in Washington State's (USA) coastal estuaries. Estuaries 23:141-76.

Gittman RK, Keller DA. 2013. Fiddler crabs facilitate Spartina alterniflora growth, mitigating periwinkle overgrazing of marsh habitat. Ecology 94:2709-18.

Holdredge C, Bertness MD, Herrmann NC, Gedan KB. 2010. Fiddler crab control of cordgrass primary production in sandy sediments. Mar Ecol Prog Ser 399:253-9.

Katz LC. 1980. Effects of burrowing by the fiddler crab, Uca pugnax (Smith). Estuar Coast Mar Sci 11:233-7.
Kiers TE, Palmer TM, Ives AR, Bruno JF, Bronstein JL. 2010. Mutualisms in a changing world: an evolutionary perspective. Ecol Lett 13:1459-74.

Kreeger DA, Newell RIE. 2001. Seasonal utilization of different seston carbon sources by the ribbed mussel, Geukensia demissa (Dillwyn) in a mid-Atlantic salt marsh. J Exp Mar Biol Ecol 260:71-91.

Labenia JS, Baldwin DH, French BL, Davis JW, Scholz NL. 2007. Behavioral impairment and increased predation mortality in cutthroat trout exposed to carbaryl. Mar Ecol Prog Ser 329:111.

Laverock B, Gilbert Jack A, Tait K, Osborn AM, Widdicombe S. 2011. Bioturbation: impact on the marine nitrogen cycle. Biochem Soc Trans 39:315-20.

Lee RW, Kraus DW, Doeller JE. 1996. Sulfide-stimulation of oxygen consumption rate and cytochrome reduction in gills of the estuarine mussel Geukensia demissa. Biol Bull 191(3):42130.

Loya Y, Sakai K, Yamazato K, Nakano Y, Sambali H, van Woesik R. 2001. Coral bleaching: the winners and the losers. Ecol Lett $4: 122-31$

Martinetto P, Montemayor DI, Alberti J, Costa CSB, Iribarne O. 2016. Crab bioturbation and herbivory may account for variability in carbon sequestration and stocks in south west atlantic salt marshes. Front Mar Sci 3:122

Mayer FL. 1987. Acute toxicity handbook of chemicals to estuarine organisms, Gulf Breeze, Florida. US Environmental Protection Agency (EPA-600/8-017)

Mendelssohn IA. 1979. Nitrogen metabolism in the height forms of Spartina alterniflora in North Carolina. Ecology 60:574-84.

Naddafi R, Eklöv P, Pettersson K. 2007. Non-lethal predator effects on the feeding rate and prey selection of the exotic zebra mussel Dreissena polymorpha. Oikos 116:1289-98.

Nielsen KJ, Franz DR. 1995. The influence of adult conspecifics and shore level on recruitment of the ribbed mussel Geukensia demissa (Dillwyn). J Exp Mar Biol Ecol 188:89-98.

Nomann BE, Pennings SC. 1998. Fiddler crab-vegetation interactions in hypersaline habitats. J Exp Mar Biol Ecol 225:5368.

Ornes WH, Kaplan DI. 1989. Macronutrient status of tall and short forms of Spartina alterniflora in a South Carolina marsh. Mar Ecol Prog Ser 55:63-72.

Peres CA, Emilio T, Schietti J, Desmoulière SJ, Levi T. 2016. Dispersal limitation induces long-term biomass collapse in overhunted Amazonian forests. Proc Natl Acad Sci 113:892-7.

Poore AG, Campbell AH, Steinberg PD. 2009. Natural densities of mesograzers fail to limit growth of macroalgae or their epiphytes in a temperate algal bed. J Ecol 97:164-75.

Riisgard H. 1988. Efficiency of particle retention and filtration rate in 6 species of Northeast American bivalves. Mar Ecol Progr Ser 45:217-23.

Robson AA, De Leaniz CG, Wilson RP, Halsey LG. 2010. Behavioural adaptations of mussels to varying levels of food availability and predation risk. J Molluscan Stud 76:348-53.

Sharp SJ, Angelini C. 2016. Whether disturbances alter salt marsh soil structure dramatically affects Spartina alterniflora recolonization rate. Ecosphere 7(11):e01540. https://doi.org/ $10.1002 /$ ecs2.1540.

Silliman BR, Zieman JC. 2001. Top-down control of Spartina alterniflora production by periwinkle grazing in a Virginia salt marsh. Ecology 82:2830-45. 
Smith SM, Tyrrell MC. 2012. Effects of mud fiddler crabs (Uca pugnax) on the recruitment of halophyte seedlings in salt marsh dieback areas of Cape Cod (Massachusetts, USA). Ecol Res 27:233-7.

Stachowicz JJ. 2001. Mutualism, facilitation, and the structure of ecological communities: positive interactions play a critical, but underappreciated, role in ecological communities by reducing physical or biotic stresses in existing habitats and by creating new habitats on which many species depend. Bioscience 51:235-46.

Stiven AE, Gardner SA. 1992. Population processes in the ribbed mussel Geukensia demissa (Dillwyn) in a North Carolina salt marsh tidal gradient: spatial pattern, predation, growth and mortality. J Exp Mar Biol Ecol 160:81-102.

Stiven AE, Kuenzler EJ. 1979. The response of two salt marsh molluscs, Littorina irrorata and Geukensia demissa, to field manipulations of density and Spartina litter. Ecol Monogr 49:151-71.

Teal JM. 1958. Distribution of fiddler crabs in Georgia salt marshes. Ecology 39:185-93.

Thomas CR, Blum LK. 2010. Importance of the fiddler crab Uca pugnax to salt marsh soil organic matter accumulation. Mar Ecol Prog Ser 414:167-77.

Thomsen MS, Wernberg T, Altieri A, Tuya F, Gulbransen D, McGlathery KJ, Holmer M, Silliman BR. 2010. Habitat cascades: the conceptual context and global relevance of facilitation cascades via habitat formation and modification. Integr Compar Biol 50:158-75.

Thomsen MS, Altieri AH, Angleini C, Bishop MJ, Gribben PE, Lear G, He Q, Schiel DR, South PM, Watson DM, Wernberg T,
Zotz G. 2018. Secondary foundation species enhance biodiversity. Nat Ecol Evol 2:634-9.

van der Heide T, Govers LL, de Fouw J, Olff H, van der Geest M, van Katwijk MM, Piersma T, van de Koppel J, Silliman BR, Smolders AJ. 2012. A three-stage symbiosis forms the foundation of seagrass ecosystems. Science 336:1432-4.

van der Zee EM, Angelini C, Govers LL, Christianen MJA, Altieri AH, van der Reijden KJ, Silliman BR, van de Koppel J, van der Geest M, van Gils JA, van der Veer HW, Piersma T, de Ruiter PC, Olff H, van der Heide T. 2016. How habitat-modifying organisms structure the food web of two coastal ecosystems. Proc R Soc B Biol Sci 283:20152326.

von Bertalanffy L. 1938. A quantitative theory of organic growth (inquiries on growth laws. II). Hum Biol 10:181-213.

Whalen MA, Duffy JE, Grace JB. 2013. Temporal shifts in topdown vs. bottom-up control of epiphytic algae in a seagrass ecosystem. Ecology 94:510-20.

Wilsey BJ, McKee KL, Mendelssohn IA. 1992. Effects of increased elevation and macronutrient and micronutrient additions on Spartina alterniflora transplant success in saltmarsh dieback areas in Louisiana. Environ Manag 16(4):50511.

Wolf P, Shanholtzer S, Reimold R. 1975. Population Estimates for Uca pugnax (Smith, 1870) on the Duplin Estuary Marsh, Georgia, U.S.A. (Decapoda Brachyura, Ocypodidae). Crustaceana 29(1):79-91.

Xu S. 2000. Environmental fate of carbaryl. Sacramento: California Environmental Protection Agency, Department of Pesticide Regulation. 